\title{
Mesenchymal stem cells in the treatment of diabetes mellitus: perspectives
}

\author{
Olga Ulyanova $^{1}$, Temirlan Karibekov ${ }^{2}$, Galiya Shaimardanova ${ }^{2}$, Larissa Kozina ${ }^{3}$
}

${ }^{1}$ Endocrine Disturbances Department, National Scientific Medical Center, Astana, Republic of Kazakhstan

${ }^{2}$ Scientific Research Management Department, National Scientific Medical Center, Astana, Republic of Kazakhstan

${ }^{3}$ Clinical and Diagnostic Laboratory, National Scientific Medical Center, Astana, Republic of Kazakhstan

\section{This work is licensed under a} Creative Commons Attribution 4.0 International License

\section{Received: 2018-09-20}

Accepted: 2018-10-15

UDC: 616.1

\section{J Clin Med Kaz 2018;3(49):32-34}

Corresponding Author: Olga Ulyanova, Endocrine Disturbances Department, National Scientific Medical Center. Address: 42, Abylay khan avenue, 010009, Astana, Republic of Kazakhstan. Tel.: + 77013838107

E-mail: olgaulyanova1971@gmail.com

\section{Abstract}

Over recent decades, diabetes mellitus remains one of the main public healthcare problems worldwide with a tendency to steady growth. Actual prevalence of only type 2 diabetes mellitus among adults (20-79 years old) in Kazakhstan was higher than it was expected and amounted to $8.2 \%$ according to the Kazakh epidemiological study NOMAD. Diabetes mellitus is a major risk factor for ischemic heart disease and stroke, which collectively account for high rates of morbidity and mortality among adult patients. Transplantation of mesenchymal stem cells was considered to be the most promising treatment approach for diabetes mellitus.

Key words: c-peptide, adipokines, pancreatic islet cell regeneration

\section{ҚАНТТЫ ДИАБЕТТІ ЕМДЕУДЕГІ МЕЗЕНХИМАЛЬДЫ БАҒАНАЛЫҚ ЖАСУШАЛАРЫН ҚОЛДАНУДЫН КЕЛЕШЕГІ}

Ульянова О.В. ${ }^{1}$, Карибеков Т. С. ${ }^{2}$, Шаймарданова Г. М. ${ }^{2}$, Козина Л. В. ${ }^{3}$

эЭндокриндік аурулар бөлімі, Ұлттық ғылыми медициналық орталық, Астана, Қазақстан Республикасы

${ }^{2}$ Ғылыми зерттеулер менеджменті бөлімі, Ұлттық ғылыми медициналық орталық, Астана, Қазақстан Республикасы

${ }^{3}$ Клиникалық және диагностикалық зертханасы, Ұлттық ғылыми медициналық орталық, Астана, Қазақстан Республикасы

\section{тұЖЫРЫМДАМА}

Қантты диабет жылма-жыл өсу тенденциясымен әлемдегі ең көбірек таралған инфекциялық емес аурулардың бірі болып қалуда. NOMAD эпидемиологиялық зерттеу деректері бойынша 2-ші типтегі қантты диабеттің Қазақстанның ересек халқы (20-79 жас) арасында нақты таралуы болжанған шамадан жоғары болып шықты және 8,2\%-ды құрады. Қантты диабеттің мүгедектікке және өлім-жітімге соқтыратын асқыну себептері мен қоса болатын аурулары өте қауіпті. Мезенхимальды бағаналық жасушасын транспланттау қантты диабетті емдеуде жаңа перспективаларды ашуда, олар болашақта транспланттауға жарамды инсулин-өндіруші тінді алудың көзі болып қаралуда.

Негізгі сөздер: с-пептид, адипокиндер, панкреатиялық клеткалардың қалпына келу

\section{ПЕРСПЕКТИВЫ ПРИМЕНЕНИЯ МЕЗЕНХИМАЛЬНЫХ СТВОЛОВЫХ КЛЕТОК В ЛЕЧЕНИИ САХАРНОГО ДИАБЕТА}

Ульянова О.В. ${ }^{1}$, Карибеков Т. С. ${ }^{2}$, Шаймарданова Г. М. ${ }^{2}$, Козина Л. В. ${ }^{3}$

'Отдел эндокринных нарушений, Национальный научный медицинский центр, Астана, Республика Казахстан

${ }^{2}$ Отдел менеджмента научных исследований, Национальный научный медицинский центр, Астана, Республика Казахстан

${ }^{3}$ Клинико-диагностическая лаборатория, Национальный научный медицинский центр, Астана, Республика Казахстан

\section{PEЗЮME}

Согласно литературным данным, сахарный диабет остается одним из наиболее распространенных неинфекционных заболеваний во всем мире с тенденцией к неуклонному росту. По данным эпидемиологического исследования NOMAD, реальная распространенность только сахарного диабета типа 2 среди взрослого населения (20-79 лет) Казахстана оказалась выше предполагаемой и составила 8,2\%. Сахарный диабет является фрактором риска развития ишемической болезни сердца и периферических поражений сосудов, которые являются причиной высокой инвалидизации и смертности среди взрослого населения. Трансплантация мезенхимальных стволовых клеток рассматривается как перспективное направление лечения сахарного диабета.

ключевые слова: с-пептид, адипокины, панкреатическая клеточная регенерация, стволовые клетки 
Согласно литературным данным, сахарный диабет (СД) остается одним из наиболее распространенных неинфекционных заболеваний во всем мире с тенденцией к неуклонному росту [1]. Так, по оценке International Diabetes Federation (IDF) в 2015 году в мире насчитывалось 415 млн. пациентов с СД, к 2040 г. их количество достигнет 642 млн. человек[2].Попрогнозамэкспертов IDF, распространенность СД в Казахстане среди взрослого населения (20-79 лет) составляет $6,2 \%$, при этом затраты здравоохранения на одного пациента с СД составляют 834,9 доллара США, а число случаев смерти вследствие СД составляет - 10 610,3 [2]. Однако, как показало эпидемиологическое исследование NOMAD, реальная распространенность только СД типа 2 среди взрослого населения (20-79 лет) Казахстана оказалась выше предполагаемой и составила $8,2 \%$ [3]. Как известно, опасен не сам СД, а его осложнения и сопутствующие заболевания, такие как нефропатия, сосудистые осложнения (ишемическая болезнь сердца, периферические поражения сосудов), ретинопатия, которые являются причиной высокой инвалидизации и смертности. Несмотря на успехи в создании новых видов инсулина и его аналогов в виде сверхкоротких и пролонгированных форм, внедрение помповой инсулинотерапии и систем непрерывного мониторинга глюкозы, а также искусственной поджелудочной железы, проблема удовлетворительного контроля гликемии как у пациентов с СД типа 1, так и СД типа 2 остается по-прежнему актуальной $[1,2]$.

До настоящего времени попытки трансплантации фрагментов поджелудочной железы и островков Лангерганса были связаны с трудностями из-за отторжения трансплантата и побочных эффектов и осложнений, связанных с применением иммуносупрессивной терапии [3]. Поэтому трансплантация инсулинпродуцирующих клеток является наиболее перспективным методом лечения СД [5, 6]. Имеются успехи в трансплантации эмбриональных и фетальных стволовых клеток (СК) [7, 8]. Однако, широкое их применение ограничивается этическими аспектами.

В связи с этим, открытие плюрипотентных мезенхимальных СК открывает новые перспективы в лечении СД. Мезенхимальные СК, полученные из жировой ткани или костного мозга, обладают способностью дифференцироваться в эктодермальные (нервные), мезодермальные (сосудистый эндотелий) и эндодермальные (печень, поджелудочная железа) типы клеток в присутствии определенных цитокинов и факторов роста $[9,10]$. Следовательно, мезенхимальные СК рассматриваются как возможный источник получения пригодной для трансплантации инсулин-продуцирующей ткани $[11,12]$. Последние исследования показали возможность получения дифференцированных $\beta$-клеток in vitro, в том числе из собственных мезенхимальных СК организма, так как не вызывают отторжения трансплантата $[12,14]$. Кроме того, установлено, что СК обладают иммуносупрессивным действием в отношении цитотоксических Т-лимфоцитов и способностью регулировать иммунные процессы [15-17].
Полагают, что введенные мезенхимальные СК костного мозга способны стимулировать синтез эндогенного фактора роста гепатоцитов, индуцируя тем самым регенерацию $\beta$-клеток в островках Лангерганса поджелудочной железы [18]. Так, было показано, что после трансплантации СК костного мозга крысам со стрептозотоциновой моделью СД типа 1 отмечено более чем 8-кратное увеличение содержания эндогенного фактора роста гепатоцитов в сыворотке крови животных по сравнению с группой контроля. В более ранних исследованиях показано, что в периоде эмбриогенеза мезенхимальные СК опосредованно за счет синтеза эндогенного фактора роста гепатоцитов стимулируют дифференцировку эпителиальных клеток протоков в инсулин-продуцирующие клетки [19, 20].

Другим важным свойством СК является стимуляция неоангиогенеза - как за счет прогениторных клеток, способных дифференцироваться в эндотелиоциты, так и за счет выделяемых ими регуляторных факторов $[18,21]$. Особенно большое значение это свойство мезенхимальных СК имеет для больных СД типа 1, у которых вследствие многочисленных метаболических нарушений и окислительного стресса резко снижено количество предшественников эндотелиальных клеток, что приводит к развитию различных сосудистых осложнений (микроангиопатий), а также является фактором торможения регенерации островков Лангерганса [22].

Применение СК костного мозга может быть перспективным также для лечения СД типа 2, патогенез которого отличается от патогенеза СД типа 1 тем, что в основе заболевания лежит инсулинорезистентность, которая обусловлена мембранной патологией клеток, реализующейся в условиях дислипидемии [23-25].

В ряде экспериментальных и клинических исследований показана также клиническая эффективность использования мезенхимальных СК как при СД типа 1, так и типа 2. Так, у большинства пациентов в течение 1 года после трансплантации снижалась потребность в инсулине, повышался уровень С-пептида [26].

Изучены механизмы влияния клеточной трансплантации на регуляцию аутоиммунитета и уровня лептина при СД 1 типа. В ряде работ показано, что клеточная трансплантация при СД типа 1 не приводит к росту уровня антител к островкам Лангерганса. Кроме того, выявлено, что клеточная трансплантация приводит к повышению уровня лептина наряду с увеличением уровня С-пептида, что свидетельствует об эффективности трансплантации [2729].

Все вышеизложенное открывает широкие перспективы для изучения процессов, объясняющих механизмы воздействия СК на различные звенья патогенеза СД с целью их дальнейшего использования как для лечения аутоиммунного СД типа 1, так и для СД типа 2.

Disclosures: There is no conflict of interest for all authors.

\section{Список литературы}

1. Dedov II, Balabolkin MI, Klebanova EM, Kreminskaya VM, Tchazova T.E. Diabetes mellitus: pathogenesis, classification, diagnostic and treatment [in Russian]. Medicine; 2003. p.171.

2. Atlas IDF-7th edition, 2015. Available from: www.diabetesatlas.org

3. Tokhtarova N, Bazarbekova R, Dosanova A. Prevalence of type 2 diabetes mellitus among adult population of Kazakhstan [in Russian]. Medicine. 2017;6(180):43-51. 
4. Robertson RP. Islet transplantation as a treatment for diabetes - a work in progress. A new therapeutic concept. $N$ Engl $J$ Med.2004;7(350):694-705.

5. Bretzel RG, Jahr H, Eckhard M. et al. Islet cell transplantation today. Langenbecks Arch Surg.2007:392(3):239-253.

6. Sheremetyeva ME, Bukharova T., Goldshtein DV. Insulinproduced cells in treatment of insulindependent diabetes mellitus [in Russian]. Genes and cells.2016;1:24-34.

7. Tuganbekova S, Ulyanova O, Taubaldieva Z, Saparbayev S, Popova N, Kozina L. Fetal pancreatic stem-cell transplant in patients with diabetes mellitus. Exp Clin Transplant. 2015;13(Suppl 3):160-162.

8. Ulyanova O, Taubaldieva Z, Tuganbekova S, et al. Leptin level in patients with type 2 diabetes mellitus after fetal pancreatic stem cell transplant. Exp Clin Transplant. 2016;14(Suppl 3):45-47.

9. Nikonova T, Pekarskaya E, Filippov Yu. Perspectives of applications of stem-cells technologies in treatment of diabetes mellitus [in Russian]. Vrach. 2010; 12:10-13.

10. Borisov MA, Petrakova OS, Gvazava IG. et al. Stem Cells in the Treatment of insulin-dependent diabetes mellitus. Acta Naturae. 2016; 8.(30):31-43.

11. Dedov II, Lisukov IA, Laptev DN. The modern possibilities of stem cells using in diabetes mellitus [in Russian]. Diabetes mellitus. 2014;(2):20-28.

12. Zakiryanov AR, Onischenko NA, Klimenko ED, Pozdnyakov OM. Regeneration stem-cells therapy of diabetes mellitus type 1 and it complications [in Russian].Vestnik RAMS. 2008;3:42-51.

13. Abdi R, Fiorina P, Adra CN, Atkinson M, Sayegh MH. Immunomodulation by mesenchymal stem cells: a potential therapeutic strategy for type I diabetes. Diabetes.2008; 57:1759-1767.

14. Alvarez-Dolado M. Cell fusion: biological perspectives and potential for regenerative medicine. Front Biosci.2007; $12:$ P.1-12.

15. You S, Thieblemont N, Alyanakian M, Bach JF, Chatenoud L. Transforming growth factor-beta and T-cell-mediated immunoregulation in the control of autoimmune diabetes. Immunol Rev. 2006; 212:185-202.

16. Kehrl JH. Transforming growth factor-beta: an important mediator of immunoregulation. Int J Cell Cloning. 1991;9(5):438-450.

17. Daneshmandi S, Karimi MH, Pourfathollah AA. TGF- $\beta 1$ transduced mesenchymal stem cells have profound modulatory effects on DCs and T cells. Iran J Immunol. 2017;14(1):13-23.

18. Kurabekova R, Shevchenko O, Tsiroulnikova O. Transforming growth factor $\beta 1$ at liver transplantation [in Russian]. Russ $J$ Transpl Artif Org.2015;3:76-82.

19. Zulewski H. Stem cells with potential to generate insulin-producing cells in man. SWISS MED WKLY. 2006;136:647-654.

20. Shiraki N, Ogaki S, Kume S. Profiling of embryonic stem cell differentiation. Rev Diabet Stud. 2014;11(1):102-114.

21. Jing Shen, Yu Cheng, Qingwang Han, Yiming Mun et al . Generating insulin-producing cells for diabetic therapy: Existing strategies and new development. Ageing Research Reviews. 2013;12(2):469-478.

22. Marius Strioga, Sowmya Viswanathan, Adas Darinskas et al. Same or Not the Same? Comparison of adipose tissue-derived versus bone marrow-derived mesenchymal stem and stromal cells. Stem Cells and Development. 2012:4;2724-2752.

23. Fisher S, Hanefeld M, Haffner SM, et al. Insulin-resistant patients with type 2 diabetes mellitus have higher serum leptin levels independently of body fat mass. Acta Diabetol. 2002;39(3):105-110.

24. Haojie Hao, Jiejie Liu, Jing Shen et al. Multiple intravenous infusions of bone marrow mesenchymal stem cells reverse hyperglycemia in experimental type 2 diabetes rats. Biochemical and Biophysical Research Communications. 2013;436(3):418423

25. Shobhit B, Pinaki D, Vinod K et al. Efficacy of autologous bone marrow-derived mesenchymal stem cell and mononuclear cell transplantation in type 2 diabetes mellitus: a randomized, placebo-controlled comparative study. Stem Cells and Development. April 2017; 26(7): 471-481.

26. Zang L., Hao H., Liu J et al. Mesenchymal stem cell therapy in type 2 diabetes mellitus. Diabetol Metab Syndr. 2017;2: 9-36.

27. Cummings BP, Bettaieb A, Graham JL, et al. Subcutaneous administration of leptin normalizes fasting plasma glucose in obese type 2 diabetic UCD-T2DM rats. Proc Natl Acad Sci U S A. 2011;108(35):14670-14675.

28. Denroche HC, Huynh FK, Kieffer TJ. The role of leptin in glucose homeostasis. J Diabetes Investig. 2012;3(2):115-129.

29. Meek TH, Morton GJ. The role of leptin in diabetes: metabolic effects. Diabetologia. 2016;59(5):928-932.

How to cite this article: Olga Ulyanova, Temirlan Karibekov, Galiya Shaimardanova, Larissa Kozina. Mesenchymal stem cells in the treatment of diabetes mellitus: perspectives [in Russian]. J Clin Med Kaz. 2018; 3(49):32-34 